\title{
QUALITY OF LIFE AND DEPRESSION IN PATIENTS UNDERGOING TOTAL AND PARTIAL LARYNGECTOMY
}

Daniella Scalet Amorin Braz, Marta Maria Ribas, Rogério Aparecido Dedivitis, Inês N. Nishimoto, and Ana Paula Brandão Barros

BRAZ DAS et al. Quality of life and depression in patients undergoing total and partial laryngectomy. CLINICS 60(2):135$142,2005$.

PURPOSE: The surgical treatment of head and neck cancer, primarily laryngeal cancer, causes sequelae and can change the patient's quality of life. The purpose of this study was to investigate the impact of laryngectomy on the quality of life regarding the functional, physical, psychological, and social aspects.

METHODS: Fourteen patients underwent total laryngectomy and 16 underwent vertical partial laryngectomy. The Quality of Life Core Questionnaire (QLQ-C30) and Head and Neck (H\&N35) questionnaire from the European Organization for Research and Treatment of Cancer (EORTC) were used for quality of life evaluation, while the Beck Depression Inventory questionnaire was used for the depression screen.

RESULTS: In the total laryngectomy group, reported adverse effects were worsened, social and emotional function $(21.3 \%)$, olfaction and taste changes (85.6\%), cough (71.3\%), speech difficulty (100\%), and dysphagia (64.3\%). Most of the patients $(85.5 \%)$ judged their quality of life to be reasonable. In the partial laryngectomy group, reported adverse effects were worsened, emotional function (71.4\%), speech difficulty (100\%), and dysphagia (31.3\%). However, most of the patients judged their quality of life to be above the general average.

CONCLUSION: Despite being different surgeries, both groups experienced similar difficulties but at different levels. The quality of life was judged worse in the patients who underwent total laryngectomy.

KEYWORDS: Quality of life. Laryngeal neoplasm. Laryngectomy. Depression. Voice.

Head and neck cancer and its treatment change some of the most basic and important vital functions such as breathing, feeding, oral communication, and social interaction. The modified appearance, the absence of the usually employed voice, the difficulty in swallowing, and some problems in the oncologic treatment, such as development of fistula and mucositis, interfere in the quality of life of the patient, bringing everyday limitations. ${ }^{1}$

The clinical staging and the site of the larynx cancer will indicate the different forms of treatment and consequently of rehabilitation, with different impacts on the qual-

From the Head and Neck Surgery Discipline, Santos Metropolitan University - Santos/SP, Brazil.

E-mail: apbbarros@uol.com.br

Received for publication on June 08, 2004

Accepted for publication on January 06, 2005. ity of life of the patient. These impacts must be well understood by both the treatment team and the patients so that all involved are pleased with the results.

Quality of life can be defined as a subjective evaluation that people make about the different aspects of their lives in correlation with their health. ${ }^{2}$ It involves not only a successful surgery from the oncologic point of view but also personal life as a whole. ${ }^{3}$

Prospective studies on head and neck surgery regarding the quality of life are important, not only for the patients who are going to get extensive interventions but also for those who are part of multidisciplinary protocols. The subject requires studies in which each item receives quantitative values so that they can be analyzed through a scientific point of view, thus withdrawing the subjective weight of the individual experience. ${ }^{4}$ Apart from the changes brought on by 
the treatment, which eventually generate emotional and social difficulties, depression is another enhancing factor that must be taken into consideration.

The purpose of this study was to assess the impact on quality of life and screen for depression in the patients who underwent different surgical treatments for laryngeal cancer.

\section{METHOD}

Thirty patients were studied, divided into 2 groups according to the surgery performed: group 1 (total laryngectomy) and group 2 (vertical partial laryngectomy). The total laryngectomy group consisted of 14 patients, 12 men and 2 women with an average of 61 years of age. In this group, 11 patients underwent radiation therapy, receiving an average of $6.375 \mathrm{cGy}$. Three patients communicated with an esophageal voice associated with gestures, 4 through a tracheoesophageal voice, 1 through an electrolarynx and 6 used other forms of non-oral communication including graphics, gestures, and articulated speech. Ten patients underwent speech therapy in order to rehabilitate the alaryngeal oral communication.

The group receiving vertical partial laryngectomy consisted of 16 patients, 15 men and 1 woman, average age of 63.5 years of age. Three patients underwent radiation therapy receiving an average total dose of $6.773 \mathrm{cGy}$. In this group, 13 underwent frontolateral laryngectomy with reconstruction using a bipedicle flap of the sternohyoid. At the time of recruitment, no patients had a tracheotomy and none of them reported breathing discomfort. Regarding voice quality, all the patients presented some components of roughness, straining, or breathiness at varying levels, ranging from mild to moderate, but none claimed difficulties in the intelligibility of the communication or effort to speak. Six patients underwent speech therapy after the surgery.

Patients completed the quality of life questionnaires (QLQ-Core30 and QLQ-Head and Neck35) and the depression screen (Beck Depression Inventory). The minimum interval between surgery and completion of the questionnaires was 4 months so as to avoid inadequate results due to posttreatment functional adaptation. We were also careful not to assess patients at the very same time as the post-surgery adjuvant radiation therapy. The questionnaires were presented by a professional who did not have contact with the patients during their treatment so as not to inhibit free responses to the questions.

The European Organization of the Research and Treatment of Cancer (EORTC), quality of life questionnaire (is an instrument of self-applied evaluation that has 5 functional scales -daily activities, leisure and job, cognitive, emotional, and social, a scale of the global quality of life;
3 scales for symptoms -fatigue, nausea and vomiting, and pain, and 6 individual items - breathlessness, appetite reduction, sleep disturbance, constipation, diarrhea, and financial difficulties. ${ }^{5,6}$

The scores were calculated according to the EORTC QLQ-C307 manual, where the score of the points is modified into a scale from 0 to 100 . A high score on the functional scale indicates a good quality of life, and a high score on the scale of the symptoms and individual items indicates an increased level of symptoms and problems. The specific head and neck module (H\&N35) consists of questions that reveal problems related to the site of the tumor and its respective treatment, being a complement to the QLQ-C30 questionnaire. The scores were calculated according to the EORTC QLQ-C307 scoring manual.

The Beck Depression Inventory is an instrument for measuring depressive behavior, being self-applied and containing 21 multiple choice questions with answers from 0 to 3. The test has two interpretations, one for psychiatric patients and another for the global population. ${ }^{8,9}$ In this study, the interpretation level for the global population questionnaire was used ( 0 to 15 - absence of the depression or presence of the mild symptoms; 15 to 20 - dysphoria, behavior changes; and 20 or more - depression). ${ }^{8}$

The nonparametric Mann-Whitney U test was applied to verify the difference between the total or partial laryngectomy groups, and a nonparametric Kruskal-Wallis test was performed to examine the type of the communication and quality of life of the patients treated with total laryngectomy in relation to the continuous variables. To verify the association between depression screen variables and the groups of surgery, the parametric Student $t$ test was used. The significance level of $5 \%$ was adopted for all tests.

\section{RESULTS}

The median score for global quality of life was identical (83.3) for the two groups. Regarding the type of communication, the patient having a partial laryngectomy who communicated using an electrolarynx had the worst score for the quality of life. Patients who underwent a partial laryngectomy and who used other types of oral communication obtained higher scores. In the group receiving partial laryngectomies, all patients maintained laryngeal communication with some component of roughness, strain, or breathiness, varying from mild to moderate (Table 1).

In the group that underwent total laryngectomy, the median of the functional scale was significantly worse for social function items $(P=.019)$ and for the daily activities, though this latter difference was not a significant difference $(P=.376)$ compared to the partial laryngectomy group. For the emo- 
tional item, no significant difference occurred for the medians between total and partial laryngectomy groups $(P=.932)$.

For the symptoms and individual items scales, the total laryngectomy group scored the worst on the the fatigue item $(P=.010)$ and financial difficulties item $(P=.024)$ (Table 2$)$.

On the symptoms scale of the specific head and neck module (H\&N35), the patients of the total laryngectomy group had more complaints than the partial laryngectomy group (Table 3 ).

The results from the questionnaire that screens mood alterations - the Beck Depression Inventory - indicated that 3 patients had signs of dysphoria, with 2 from the total la- ryngectomy group and 1 from the other group. Only 1 patient from the total laryngectomy group had a score indicating depression (Table 4).

The average and median score in the Beck Depression Inventory of the partial laryngectomy group (7 and 6 respectively) were lower than those of the total laryngectomy group (10 and 8.3, respectively, $P=.039$ ) (Table 5). For the patients whose scores indicated for dysphoria, only 1 case in the partial laryngectomy group scored 16, and in the total laryngectomy group, 1 patient scored 16 and another 18. The only patient with a case of the depression had a score of 24 and was from the total laryngectomy group.

Table 1 - Result of the global quality of life and type communication in the groups of the total and partial laryngectomy groups.

\begin{tabular}{|c|c|c|c|c|c|c|c|c|c|c|}
\hline \multirow[t]{3}{*}{ Variable } & \multirow[t]{3}{*}{ Categories } & \multicolumn{8}{|c|}{ EORTC QLQ-C30 } & \multirow{3}{*}{$P$} \\
\hline & & \multicolumn{3}{|c|}{$\mathrm{TL}(\mathrm{n}=14)$} & \multicolumn{4}{|c|}{ PL $(n=16)$} & \multirow[b]{2}{*}{ Mean (sd) } & \\
\hline & & Min. & Max. & Median & Mean (sd) & Min. & Max. & Median & & \\
\hline $\begin{array}{l}\text { Global quality } \\
\text { of life }\end{array}$ & & 50 & 100 & 83.3 & $77.4(16.5)$ & 50 & 100 & 83.3 & $81.2(14.7)$ & .468 \\
\hline \multirow{5}{*}{$\begin{array}{l}\text { Type of } \\
\text { communication }\end{array}$} & $\operatorname{TEV}(\mathrm{n}=4)$ & 80 & 100 & 86.6 & $88.3(8.4)$ & & & & & \multirow[t]{5}{*}{$.617 *$} \\
\hline & $\mathrm{EV}(\mathrm{n}=3)$ & 73.3 & 100 & 93.3 & $88.9(13.9)$ & & & & & \\
\hline & $\operatorname{EL}(\mathrm{n}=1)$ & 60 & 60 & 60 & $60(-)$ & & & & & \\
\hline & Others $(\mathrm{n}=6)$ & 86.6 & 100 & 93.3 & $93.3(6.0)$ & & & & & \\
\hline & Laryngeal voice $(\mathrm{n}=16)$ & & & & & 50 & 100 & 83.3 & $92.1(8.5)$ & \\
\hline
\end{tabular}

$P$ Value obtained from the Mann-Whitney $U$ test; $*-P$ value obtained from the Kruskal-Wallis test; the patient with the electrolarynx was excluded from this analysis; EORTC - European Organization for Research and Treatment of Cancer; QLQ - Quality of life questionnaire; C - Core; TL Total laryngectomy); PL - Partial laryngectomy; TEV - Tracheoesophageal voice; EV - Esophageal voice; EL - Electrolarynx; Others - Graphic communication, Gesticulation and articulated speech; Min. - Minimum; Max. - Maximum; sd - Standard deviation.

Table 2 - Results of the global quality of life - EORTC QLQ-C30 functional scale, symptoms scale, and individual items.

\begin{tabular}{|c|c|c|c|c|c|c|c|c|c|c|}
\hline \multirow[t]{3}{*}{ Variable } & \multirow[t]{3}{*}{ Categories } & \multicolumn{8}{|c|}{ EORTC QLQ-C30 } & \multirow{3}{*}{$P$} \\
\hline & & \multicolumn{4}{|c|}{$\mathrm{TL}(\mathrm{n}=14)$} & \multicolumn{4}{|c|}{ PL $(n=16)$} & \\
\hline & & Min. & Max. & Median & Mean (sd) & Min. & Max. & Median & Mean (sd) & \\
\hline \multirow[t]{5}{*}{ Functional Scale } & Daily activities & 60 & 100 & 90 & $88.6(11.9)$ & 73.3 & 100 & 93.3 & $92.1(8.5)$ & .376 \\
\hline & Leisure and job & 16.7 & 100 & 100 & $85.7(27.6)$ & 66.6 & 100 & 100 & $95.8(9.6)$ & .415 \\
\hline & Emotional & 33.3 & 100 & 87.5 & $76.8(24.3)$ & 50 & 100 & 83.3 & $81.8(15.6)$ & .932 \\
\hline & Cognitive & 66.6 & 100 & 100 & $91.7(14.2)$ & 66.6 & 100 & 100 & $94.8(10)$ & .668 \\
\hline & Social & 0 & 100 & 83.3 & $69.0(37.4)$ & 50 & 100 & 100 & $93.7(13.4)$ & .019 \\
\hline \multirow[t]{3}{*}{ Symptoms Scale } & Fatigue & 0 & 66.6 & 11.1 & $15.1(18.8)$ & 0 & 22.2 & 0 & $2.8(6.4)$ & .010 \\
\hline & Nausea and vomiting & 0 & 50 & 0 & $4.8(13.7)$ & 0 & 16.6 & 0 & $1.0(4.2)$ & .448 \\
\hline & Pain & 0 & 66.6 & 0 & $8.3(18.2)$ & 0 & 33.3 & 0 & $8.3(12.2)$ & .617 \\
\hline \multirow[t]{6}{*}{ Individuals Items } & Breathless & 0 & 33.3 & 0 & $9.5(15.6)$ & 0 & 33.3 & 0 & $6.2(13.4)$ & .532 \\
\hline & Insomnia & 0 & 66.6 & 0 & $14.2(21.5)$ & 0 & 33.3 & 0 & $8.3(14.9)$ & .466 \\
\hline & Lost of the appetite & 0 & 33.3 & 0 & $4.8(12.1)$ & 0 & 0 & 0 & $0(-)$ & .123 \\
\hline & Constipation & 0 & 33.3 & 0 & $7.1(14.2)$ & 0 & 66.6 & 0 & $12.5(23.9)$ & .693 \\
\hline & Diarrhea & 0 & 0 & 0 & $0(-)$ & 0 & 33.3 & 0 & $2.1(8.3)$ & .349 \\
\hline & Financial difficulty & 0 & 100 & 33.3 & $35.8(40.2)$ & 0 & 66.6 & 0 & $8.3(19.2)$ & .024 \\
\hline
\end{tabular}

$P$ - Value obtained from the Mann-Whitney U test; EORTC - European Organization for Research and Treatment of Cancer; QLQ - Quality of life questionnaire; C -Core; TL - Total laryngectomy; PL - Partial laryngectomy; Min. - Minimum; Max. - Maximum; sd - Standard deviation. 
Table 3 - Results of the quality of life of the head and neck specific module EORTC H\&N35 - symptom scale and additional information of scale.

\begin{tabular}{|c|c|c|c|c|c|c|c|c|c|c|}
\hline \multirow[t]{3}{*}{ Variable } & \multirow[t]{3}{*}{ Categories } & \multicolumn{8}{|c|}{ EORTC QLQ-H\&N35 } & \multirow{3}{*}{$P$} \\
\hline & & \multicolumn{3}{|c|}{$\mathrm{TL}(\mathrm{n}=14)$} & \multicolumn{5}{|c|}{ PL $(n=16)$} & \\
\hline & & Min. & Max. & Median & Mean (sd) & Min. & Max. & Median & Mean (sd) & \\
\hline \multirow[t]{13}{*}{ Symptoms Scale } & Pain & 0 & 41.6 & 0 & $6.5(13.5)$ & 0 & 41.6 & 0 & $5.2(11.7)$ & .809 \\
\hline & Swallowing & 0 & 66.6 & 8.3 & $11.3(16.5)$ & 0 & 58.3 & 0 & $7.3(15.5)$ & .150 \\
\hline & Sensibility & 16.6 & 100 & 50 & $54.8(23.9)$ & 0 & 33.3 & 0 & $4.2(9.6)$ & $<.001$ \\
\hline & Speech & 0 & 77.7 & 33.3 & $37.3(28.8)$ & 0 & 77.7 & 16.6 & $21.5(20.0)$ & .183 \\
\hline & Social Food & 0 & 58.3 & 8.3 & $13.1(18.7)$ & 0 & 16.6 & 0 & $1(4.2)$ & .003 \\
\hline & Social Contact & 0 & 66.6 & 6.6 & $10.5(17.8)$ & 0 & 20 & 0 & $5.9(7.6)$ & .545 \\
\hline & $\downarrow$ Sexuality & 0 & 100 & 8.3 & $25(33.2)$ & 0 & 33.3 & 0 & $5.2(10)$ & .078 \\
\hline & Teeth & 0 & 66.6 & 0 & $7.1(19.3)$ & 0 & 33.3 & 0 & $4.2(11.4)$ & .832 \\
\hline & Open of the mouth & 0 & 100 & 0 & $14.3(28.4)$ & 0 & 33.3 & 0 & $2.0(8.3)$ & .101 \\
\hline & Dry Mouth & 0 & 100 & 33.3 & $33.3(21.8)$ & 0 & 66.6 & 0 & $14.3(21.5)$ & .057 \\
\hline & Thick Saliva & 0 & 33.3 & 0 & 11.9 (16.6) & 0 & 100 & 0 & $18.7(32.1)$ & .900 \\
\hline & Cough & 0 & 100 & 33.3 & $38.1(34.2)$ & 0 & 100 & 33.3 & $27.1(27.8)$ & .370 \\
\hline & Feeling Sick & 0 & 66.6 & 0 & $9.5(20.3)$ & 0 & 33.3 & 0 & $4.2(11.4)$ & .480 \\
\hline \multirow{5}{*}{$\begin{array}{l}\text { Additional } \\
\text { Information } \\
\text { of Scale }\end{array}$} & Took Drug & 0 & 100 & 0 & $28.6(46.9)$ & 0 & 100 & 0 & $31.2(47.9)$ & .875 \\
\hline & Food Supplements & 0 & 100 & 0 & $7.1(26.7)$ & 0 & 0 & 0 & $0(-)$ & .285 \\
\hline & Feeding Food & 0 & 0 & 0 & $0(-)$ & 0 & 0 & 0 & $0(-)$ & - \\
\hline & $\downarrow$ Weight & 0 & 100 & 0 & $21.4(42.6)$ & 0 & 0 & 0 & $0(-)$ & - \\
\hline & $\uparrow$ Weight & 0 & 100 & 0 & $28.6(46.9)$ & 0 & 100 & 50 & $50.0(51.6)$ & .239 \\
\hline
\end{tabular}

$P$ - Value obtained from the Mann-Whitney U test; EORTC - European Organization for Research and Treatment of Cancer; QLQ - Quality of life questionnaire; $p$--H\&N - Head and neck; TL - Total laryngectomy; PL - Partial laryngectomy; Min. - Minimum; Max. - Maximum; sd - Standard deviation.

\section{DISCUSSION}

It is known that early diagnosis and treatment performed by specialists will result in better quality of life when compared to managing advanced tumors that require aggressive treatment leading to a worse quality of life.

This study was retrospective, so it was not possible to analyze the preoperative level of quality of life. However, some studies have analyzed the preoperative quality of life and concluded that it worsened after treatment. ${ }^{10,11}$ In our sample, the reference of normality was the score published in the EORTC QLQ-C30 Reference Values manual, ${ }^{7}$ since the preoperative data were not available.
It was not possible to recruit a larger number of patients because some of them had already presented recurrence of

Table 4 - Results of the questionnaire Beck Depression Inventory.

\begin{tabular}{lll}
\hline Variable & $\begin{array}{l}\text { TL }(\mathrm{n}=14) \\
\text { Freq. }(\%)\end{array}$ & $\begin{array}{l}\text { PL }(\mathrm{n}=16) \\
\text { Freq. }(\%)\end{array}$ \\
\hline Normal & $11(78.57)$ & $15(93.75)$ \\
Dysphoria & $2(14.28)$ & $1(6.25)$ \\
Depression & $1(7.14)$ & $0(0.0)$ \\
\hline
\end{tabular}

TL - Total laryngectomy; PL -Partial laryngectomy; Freq. Frequency

Table 5 - Results of the Beck Depression Inventory by surgery group.

\begin{tabular}{|c|c|c|c|c|c|c|c|c|c|c|}
\hline \multirow[t]{3}{*}{ Variable } & \multirow[t]{3}{*}{ Categories } & \multicolumn{8}{|c|}{ EORTC QLQ-H\&N35 } & \multirow{3}{*}{$P^{*}$} \\
\hline & & \multicolumn{3}{|c|}{$\mathrm{TL}(\mathrm{n}=14)$} & \multicolumn{5}{|c|}{ PL $(n=16)$} & \\
\hline & & Min. & Max. & Median & Mean (sd) & Min. & Max. & Median & Mean (sd) & \\
\hline Beck Depression & All & 3 & 24 & 10 & $10.6(6.0)$ & 1 & 16 & 7.5 & $6.7(3.9)$ & .0394 \\
\hline \multirow[t]{3}{*}{ Inventory } & Normal & 3 & 14 & 10 & $8.3(3.8)$ & 1 & 10 & 7.0 & $6.0(3.1)$ & .1200 \\
\hline & Dysphoria & 16 & 18 & 17 & $17(1.4)$ & 16 & 16 & 16 & $-(-)$ & NA \\
\hline & Depression & 24 & 24 & 24 & $24(-)$ & - & - & - & $-(-)$ & NA \\
\hline
\end{tabular}

$P$ - Value obtained from the Student $t$ test; TL - Total laryngectomy; PL - Partial laryngectomy; Min. - Minimum; Max. - Maximum; sd Standard deviation; NA - Not available. 
the tumor, others had died or had refused to participate. Refusal occurred because they lived in distant places, could not pay for transportation, or were not interested in taking part in the study, a pattern of behavior which has previously been observed in other similar studies. ${ }^{10,12,13}$

The findings confirmed previous expectations. The total laryngectomy group presented worse results due to definitive changes in breathing through the tracheotomy and to the absence of laryngeal communication. Although the median of the global quality of life for both groups was the same, the total laryngectomy group had worse isolated results when compared to the partial laryngectomy group. Patients who have undergone total laryngectomy develop lower levels of quality of life than patients who have undergone partial laryngectomy or other types of treatment, such as exclusive radiation therapy. ${ }^{12,14}$

Among the items researched, it was observed that the psychosocial aspects were the most affected, and the eating and speaking skills were not necessarily associated with decreased parameters of the quality of life..$^{10,15}$

The quality of life among the patients who had undergone total laryngectomy was not dependent on the type of alaryngeal communication employed. Furthermore the patients who had undergone total laryngectomy without the development of oral communication presented better scores compared to the patient in the partial laryngectomy group who had an electrolarynx. According to a previous report, ${ }^{15}$ patients who were not able to develop alaryngeal oral communication had better scores than the patients that communicated orally through some other methods.

The importance of the voice to the oral communication is well established. However, when faced with an oncologic diagnosis and the proposal of the treatment depending on tumor clinical stage, the patient may experience a shifts in priorities, highest being to stay alive and without disease. The sequelae, in which different variables are present, will be treated interpreted by the patient using different values and in a very personal way, resulting in the difficulties in measuring the quality of life.

Patients facing total laryngectomy should be advised during the preoperative period about the absence of laryngeal voice and the permanent tracheotomy. The patients referred for partial laryngectomy should be advised about the temporary tracheotomy depending on the extent of the surgery and about the dysphagia and dysphonia that are expected to occur at different levels. It is possible that the impact on the communication is not so intense for the total laryngectomized patients with oncologic advanced disease because communication through gestures or writing can be as satisfactory as the oral communication. On the other hand, and because they are able to communicate orally, partially laryn- gectomized patients, regard the development of dysphonia at different levels is not necessarily of very great importance.

Different aspects of quality of life were analyzed in our study. We observed that among those patients receiving total laryngectomies, social aspects received the worst scores. Perhaps the presence of the tracheotomy is responsible for the worse score regarding the social aspects in the total laryngectomized patients. Although some questions of the EORTC protocols are concerned with breathing, we were not able to prove the impact of the tracheotomy on the quality of life. Since in our sample, all patients in one group and none in the other group had undergone tracheotomy, the presence of a tracheotomy may have been responsible for the worse scores regarding the social aspects in the former group of patients, since it has previously been shown that a tracheotomy impairs the patient as far as the social environment is concerned. ${ }^{15}$

In a previous study, $41 \%$ of the patients were working before the total laryngectomy, and of these, only 30\% returned to their previous employment after the treatment, resulting in modification of the financial status of most of them. ${ }^{12}$ In our sample, $21 \%$ of the patients who underwent total laryngectomy reported significant financial difficulties after the treatment. This percentage would have been higher except for the fact that $60 \%$ of the patients had their own business and went back to work after the treatment had finished. Similar results were obtained in another study in which the single patient without financial difficulties had his own business and as a result kept his professional activity. ${ }^{16}$

Regarding the dry mouth item, patients who had undergone total laryngectomy had worse scores. This can be explained by the fact that most of these patients had undergone radiation therapy in which dry mouth is an expected sequel. . $^{17,18,19}$

In the total laryngectomy group, 3 patients presented mood alterations. One of them faced adverse clinical events after the surgery that could have contributed to his emotional distress. In the partial laryngectomy group, we also found a patient with dysphoria signs. All the patients were referred for professional support in the attempt to overcome the psychological problems. Patients who have undergone oncologic treatment for laryngeal cancer may or may not develop alterations in social adjustment, or depression due to several appearance-related and functional consequences, such as breathing, feeding, communication, and social interation. ${ }^{20}$ For any person undergoing surgery, there are some specific aspects that modify the psychological condition due to anxiety and depression before and after the surgery. ${ }^{21}$ Total laryngectomized patients present worse scores in the depression screen when compared to those who have undergone radiation therapy or organ preservation protocols..$^{22}$

The quality of life is a broad, subjective, and personal 
concept that deserves further investigation. Evaluating the quality of life is a difficult assignment, since it is a concept that changes according to the priorities of life of each patient. However, the sequelae of the oncologic treatment modify the social, emotional, and professional aspects, regardless of the extent of the treatment and the variations of sequelae. ${ }^{17,18,19}$

Measuring the physical, psychological, and social impacts in the life of these patients is essential for establishing parameters for the patients' rehabilitation and support. The aspects that are considered important for a better qual- ity of life during an oncologic approach differ for patients and the health staff. ${ }^{19,23}$

In spite of this, the changes observed in the total group of patients who had undergone laryngeal surgery are similar, and the global quality of life can be considered good. The degree of importance of having the capacity for oral communication is subjective in these patients.
BRAZ DAS e col. Qualidade de vida e depressão em pacientes submetidos a laringectomia total e parcial. CLINICS 60(2):135-142, 2005.

OBJETIVO: O tratamento cirúrgico para o câncer de cabeça e pescoço, especificamente para o câncer de laringe, deixa sequielas nos pacientes podendo alterar sua qualidade de vida. O objetivo deste estudo foi pesquisar o impacto na qualidade de vida, no que diz respeito aos aspectos funcionais, físicos, psicológicos, sociais e o rastreamento da depressão.

MÉTODO: Foram estudados 14 pacientes submetidos a laringectomia total e 16 pacientes submetidos a laringectomia parcial vertical. Para a avaliação da qualida- de de vida utilizamos os questionários da Organização Européia de Pesquisa e Tratamento do Câncer (EORTC), Quality of Life Core Questionnarie (QLQ-C30) e Head and Neck 35 (H\&N35) e, para o rastreamento da depressão, o questionário Beck Depression.

RESULTADOS: As funções social e emocional foram as mais afetadas no grupo de laringectomia total. $21,3 \%$ dos pacientes julgaram mediana sua qualidade de vida global. Dentro dos sintomas específicos, 85,5\% referiram alteração no olfato e paladar, 71,3\% tosse, $100 \%$ algum grau de dificuldade na fala e $64,3 \%$ dificuldades com a deglutição. No grupo de laringectomia parcial encontramos a função emocional afetada em 71,4\%, a maioria julgou sua qualidade de vida global acima da média, 100\% 
demonstraram algum grau de dificuldade com a fala e $31,3 \%$ referiram disfagia

CONCLUSÃO: Embora sendo cirurgias diferentes, ambos os grupos passaram por dificuldades similares em maior ou menor grau. Os resultados demonstraram piora nos parâmetros de qualidade de vida dos pacientes submetidos a laringectomia total.

UNITERMOS: Qualidade de vida. Neoplasias de laringe. Laringectomia. Depressão. Voz.

\section{REFERENCES}

1. List MA, Ritter-Sterr CA, Lansky SB. A performance status for head and neck cancer patients. Cancer 1990;66:654-9.

2. Font AG. Valoración de la calidad de vida en pacientes de câncer [tese de doutorado]. Bellaterra: Universidad Autónoma de Barcelona; 1988

3. Costa Neto SB, Araújo TCCF, Curado MP. Avaliação de qualidade de vida de pessoas portadoras de câncer de cabeça e pescoço. Rev. Acta Oncol. Bras. 2000 Jul-Set;20(3):96-104.

4. Brandão LG, Ferraz AR. A importância de um questionário sobre qualidade de vida em cirurgia de cabeça e pescoço. In: Brandão LO, Ferraz AR. Cirurgia de cabeça e pescoço. São Paulo, Roca, 1989. 588.

5. Aaronson NK, Ahmedzai S, Bergman B. The European Organization for Research and Treatment of Cancer QLQ-C30: a quality-of-life instrument for use in international clinical trials in Oncology. J. Natl. Cancer Inst 1993; 85: 365-76.

6. Aaronson NK, Cull AM, Kaasa S, Sprangers MAG. The European Organization for Research and Treatment of Cancer (EORTC) Modular Approach to Quality of Life Assessment in Oncology: An Update. Quality of Life and Pharmacoeconomics in Clinical Trials. In: Spilker B. (Org.). Philadelphia, Lippincott- Raven Publishers, 1996.

7. Fayers P, Aaronson NK, Bjordal K, Curran D, Groenvold M. EORTC QLQ-C30 scoring manual. $2^{\text {nd }}$ ed. Brussels, EORTC Data Center, 1999

8. Beck AT, Steer RA, Garbin MG. Psychopathology properties of the Beck Depression Inventory: Twenty five years of evaluation. Clin Psych Rev 1988;8:77-100.

9. Ferreira MC. Inventário Beck de depressão (BDI): Adaptação brasileira. Bol CEPA 1995;25-32.

10. List MA, Ritter-Sterr CA, Baker TM, Colangelo LA, Matz G, Pauloski BR, et al. Longitudinal assessment of quality of life in laryngeal cancer patients. Head Neck 1996; 18:1-9.
11. Bjordal K, Ahlner-elmqvist M, Hammerlid E, Boysen M, Evensen JF, Biörklund A, et al. A prospective study of quality of life in head and neck cancer patients, Part II: longitudinal data. Laryngoscope 2001;111:1440-52.

12. DeSanto LW, Olsen KD, Perry WC, Rohe DE, Keith RL. Quality of life after surgical treatment of cancer of the larynx. Ann Otol Rhinol Laryngol 1995;104:763-69.

13. Finizia C, Hammerlid E, Westin T, Lindström J. Quality of life and voice in patients with laryngeal carcinoma: A post-treatment comparison of laryngectomy (salvage surgery) versus Radiotherapy. Laryngoscope 1998;108:1566-73.

14. Graeff A, De Leeuw JR, Ros WJ, Hordijk GB, Blijham GH, Winnubst JA. Pretreatment factors predicting quality of life after treatment for head and neck cancer. Head Neck 2000;22:398-407.

15. Barros APB. Efetividade da comunicação oral, qualidade de vida e depressão pós-faringolaringectomia e laringectomia total. São Paulo, 2002. Dissertação (Mestrado) - Faculdade de Medicina da Universidade de São Paulo.

16. Dedivitis RA, Guimarães AV, Hushi GD, Fuza KR. Qualidade de vida do paciente laringectomizado. Rev Bras Otorrinolaringol 2000;66:7-14.

17. Fisher J, Scarantino CW, Leveque FG, White RL, Rotman M, Hodson DI, et al. Phase III quality of life study results: impact on patients' quality of life to reducing xerostomia after radiotherapy for head-and-neck cancer - RTOG 97-09. Int. J. Radiation Oncology Biol Phys 2003;56:832-36.

18. Parliament MB, Scrimger RA, Anderson SG, Kurien GC, Thompson HK, Field GC, et al. Preservation of oral health-related quality of life and salivary flow rates after inverse-planned intensitymodulated radiotherapy (IMRT) for head-and-neck cancer. Int J Radiation Oncology Biol Phys 2004;58:663-73.

19. Rampling T, King H, Mais KL, Humphris GM, Swimdell R, Syker A, et al. Quality of life measurement in the head and neck cancer radiotherapy clinic: Is it feasible and worthwhile? Clin Oncol 2003;15:205-10. 
20. Herranz J, Gavilan J. Psychosocial adjustment after laryngeal cancer surgery. Ann Otol Rhinol Laryngol1999;108:940-47.

21. Massil MJ, Chertkov L, Rolh RJ. Psychological issues: psychiatric disorders in cancer patients. In: De Vitta VT, Jr Hellman S, Rosenberg SA. Cancer: Principals and practice of oncology. $6^{\text {th }}$ ed. Philadelphia, Lippincott Williams \& Wilkins, 2001:305865 .
22. Terrell JE, Fisher SG, Olf GT. Long-term quality of life after treatment of laryngeal cancer. Arch Otolaryngol Head Neck Surg 1998;124:964-71.

23. Terrel JE, Ronis DL, Fowler KE, Bradford CR, Chepeha DB, Prince $\mathrm{ME}$, et al. Clinical predictors of quality of life in patients with head and neck cancer. Arch Otolaryngol Head Neck Surg 2004;130:401-8. 